\title{
A CONVENIENT WAY OF 3-FLUORO-1,8-NAPHTHALIMIDE SYNTHESIS
}

\author{
N.F.Fed'ko, V.F.Anikin \\ Odessa I.I.Mechnikov National University \\ 2, Dvoryanskaya Str., Odessa, 65026. E-mail: fedko@onu.edu.ua
}

Key words: 3-fluoro-1,8-naphthalic anhydride; 3-fluoro-1,8-naphthalimide; acenaphthene; Balz-Schiemann reaction

The syntheses of 3-fluoro-1,8-naphthalimide and 3-fluoro-1,8-naphthalic anhydride from 3-nitro-1,8-naphthalimide have been described. 3-Nitro-1, 8-naphthalimide can be obtained by nitration of naphthalimide with sodium nitrate in sulfuric acid. Stability of naphthalimides under acidic and alkaline conditions makes 3-substituted naphthalimides more suitable synthones for further functionalization compared to the corresponding 3-substituted naphthalic anhydrides. The best yield of 3-fluoro-1,8-naphthalimide was achieved through the following sequence: 1) nitration of naphthalic anhydride to 3-nitronaphthalic anhydride by sodium nitrate in the concentrated sulfuric acid; 2) ammonolysis of 3-nitronaphthalic anhydride to 3-nitronaphthalimide with aqueous ammonia; 3) reduction of 3-nitronaphthalimide to 3-amino-naphthalimide with sodium dithionite solution in aqueous ethanol; 4) preparation of 3-fluoronaphthalimide by diazotization of 3-aminonaphthalimide and subsequent thermal decomposition of the corresponding tetrafluoroborate. Nitration of naphthalic anhydride makes it possible to avoid the problem of poor solubility of naphthalimide in sulfuric acid. Subsequent reactions are conveniently carried out with naphthalimide derivatives, thus avoiding the difficulties encountered in isolating of 3-aminonaphthalic anhydride that can undergo a polymerization reaction. The new protocol is more efficient than the preparation route previously described leading to 3-substituted naphthalic anhydrides and naphthalimides by virtue of the substitution reaction at C-4 of acenaphthene followed by oxidation.

\begin{abstract}
ЗРУЧНИЙ ШЛЯХ СИНТЕЗУ ІМІДУ З-ФТОРО-1,8-НАФТАЛІНДИКАРБОНОВОЇ КИСЛОТИ Н.Ф.Федько, В.Ф.Анікін

Ключові слова: 3-фрторонафталімід; 3-фрторонафталевий ангідрид; аценафттен; реакція Шимана Отримано ангідрид та імід 3-фрторо-1,8-нафоталіндикарбонової кислоти з використанням як вихідних сполук нафталевого ангідриду та нафрталіміду. Показано, що 3-нітронафрталімід може бути отриманий нітруванням нафрталіміду нітратом натрію в сульфратній кислоті. Стійкість імідного циклу до дії кислот і лугів робить 3-заміщені іміди більш цінними вихідними сполуками при подальшій їх фрункціоналізації в порівнянні з відповідними 3-заміщеними нафрталевими ангідридами. Встановлено, що найкращим шляхом синтезу 3-фрторонафрталіміду, який приводить до максимального виходу иільового продукту, є наступна послідовність: 1) нітрування нафрталевого ангідриду до 3-нітронафоталіміду нітратом натрію в концентрованій сульфатній кислоті; 2) амоноліз 3-нітронафрталевого ангідриду до 3-нітронафталіміду водним розчином амоніаку; 3) відновлення 3-нітронафрталіміду до 3-амінонафрталіміду дитіонітом натрію в водно-спиртовому середовищі; 4) отримання 3-фрторонафрталіміду з 3-амінонафрталіміду через тетрафртороборат відповідної солі діазонію і далі термічним розкладанняи останньої. Нітруванням нафрталевого ангідриду вдається уникнути проблеми низької розчинності нафрталіміду в сульфатній кислоті. Наступні реакції зручніше проводити з нафрталімідним ядром, уникаючи таким чином труднощів, які виникають при виділенні 3-амінонафталевого ангідриду, здатного до гомоконденсації. Запропонований шлях є більш вигідним в порівнянні з відомим шляхом отримання 3-заміщених нафрталевих ангідридів та нафтталімідів введенням замісника в положення 4 аценафтену та подальшого окиснення.
\end{abstract}

УДОБНЫЙ ПУТЬ СИНТЕЗА ИМИДА 3-ФТОРО-1,8-НАФТАЛИНДИКАРБОНОВОЙ КИСЛОТЫ Н.Ф.Федько, В.Ф.Аникин

Ключевые слова: 3-фрторонафталимид; 3-фрторонафрталевый ангидрид; аценафттен; реакция Шимана Синтезированы ангидрид и имид 3-фрторо-1, 8-нафрталиндикарбоновой кислоты с использованием в качестве исходных веществ нафрталевого ангидрида и нафрталимида. Показано, что 3-нитронафталимид может быть получен нитрованием нафталимида нитратом натрия в серной кислоте. Устойчивость имидного кольца к действию кислот и щелочей делает 3-замещенные имиды более ценными исходными веществами при дальнейшей их функционализации по сравнению с соответствующими 3-замещёнными нафрталевыми ангидридами. Установлено, что наилучшим путем синтеза 3-фторонафталимида, приводящим к максимальному выходу целевого продукта, является следующая последовательность: 1) нитрование нафтталевого ангидрида до 3-нитронафталимида нитратом натрия в концентрированной серной кислоте; 2) аммонолиз 3-нитронафрталевого ангидрида до 3-нитронафоталимида водным раствором аммиака; 3) восстановление 3-нитронафоталимида до 3-аминонафталимида дитионитом натрия в водноспиртовой среде; 4) получение 3-фрторонафрталимида из 3-аминонафрталимида через тетрафртороборат соответствующей соли диазония и далее термическим разложением последней. Нитрованием нафрталевого ангидрида удается избежать проблемы плохого растворения нафрталимида в серной кислоте. Последующие реакции удобнее проводить с нафралимидным ядром, избежав таким образом трудностей, возникающих при выделении 3-аминонафталевого ангидрида, способного к гомоконденсации. Предложенный путь более выгоден по сравнению с известным путём получения 3-замещённых нафталевых ангидридов и нафрталимидов введением заместителя в положение 4 аценафтена и дальнейшим окислением. 


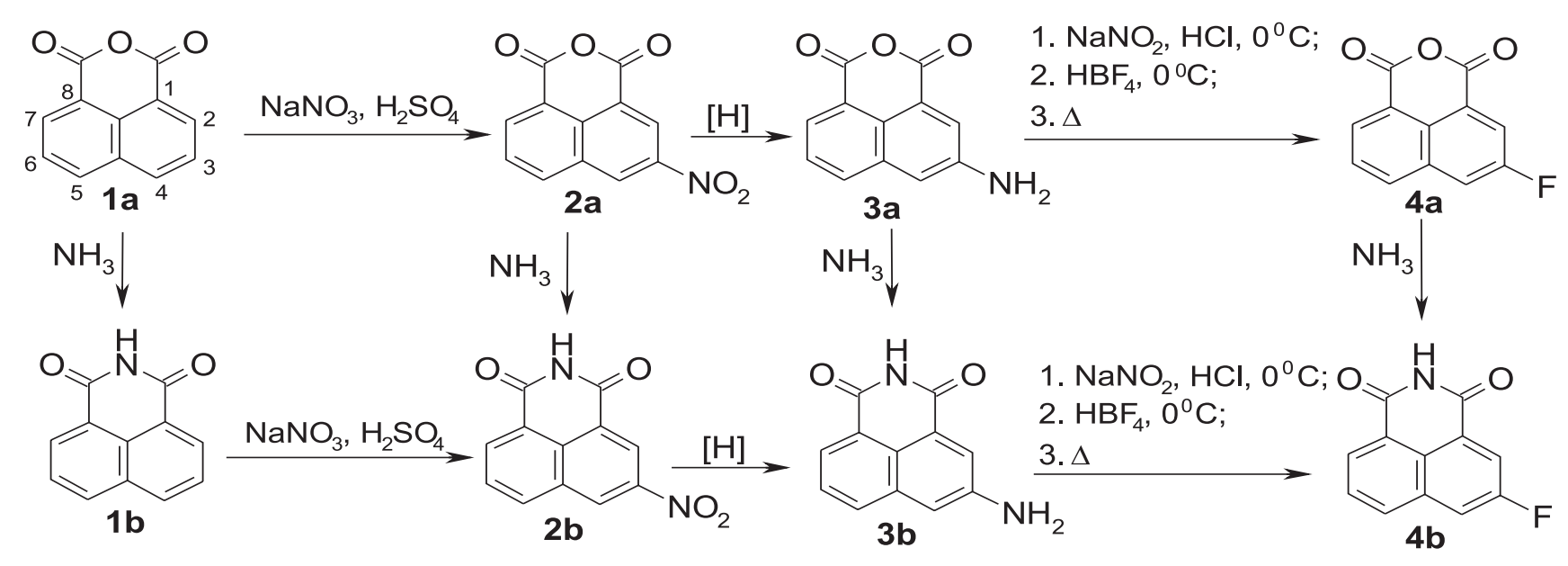

Scheme

Many derivatives of naphthalene-1,8-dicarboxylic acid imide are used as efficient fluorophores and biologically active substances. It is well known that some 3-substituted 1,8-naphthalimides possess a significant biological activity. Due to the high cytotoxic activity against various tumour cells and viruses, a number of these compounds are used as anticancer and antiviral agents [1-5].

Apparently, there are two ways to obtain 3-substituted 1,8-naphthalic anhydrides either by oxidation of the corresponding 4-substituted acenaphthene derivatives or by direct introduction of the substituent in position 3 of 1,8-naphthalic anhydride. The subsequent ammonolysis in both cases leads to the target 3-substituted 1,8-naphthalimides.

Surprisingly, there are no reports on the synthesis of 3-substituted naphthalimides from naphthalimide $\mathbf{1 b}$ as the starting material though the imide and anhydride groups have the same labilizing effect on the substituents of the naphthalene ring. Yet, importantly, the robustness of naphthalimides under acidic and alkaline conditions makes 3-substituted imides more suitable synthones for further functionalization.

3-Fluoro-, 4-fluoro- and 5-fluoroacenaphthenes were obtained by Yagupolskii \& Ivanova [6]. 4-Fluoroacenaphthene, the least accessible of three isomers, could be envisioned as the starting material for preparation of the unknown 3-fluoro-1,8-naphthalic anhydride and the corresponding imide. Therefore, the aim of the present work was to synthesize 3 -fluoro1,8-naphthalimide from readily available 1,8-naphthalic anhydride $\mathbf{1 a}$ and 1,8-naphthalimide $\mathbf{1 b}$.

The conceivable way of 3-fluoro-1,8-naphthalimide 4a preparation consists of the following steps: 1) nitration of 1,8-naphthalic anhydride $\mathbf{1 a}$; 2 ) reduction of 3-nitro-1,8-naphthalic anhydride 2a; 3) fluorination by the Balz-Schiemann reaction; 4) ammonolysis of 3-fluoro-1,8-naphthalic anhydride.

Alternatively, anhydrides $\mathbf{1 a}, \mathbf{2} \mathbf{a}, \mathbf{3} \mathbf{a}$ can be converted into the corresponding imides $\mathbf{1 b}, \mathbf{2 b}, \mathbf{3 b}$ via the ammonolysis reaction, and subsequent transformations towards $\mathbf{4 b}$ can be carried out with imides as follows from the scheme below (Scheme).

The nitration of 1,8-naphthalic anhydride and 1,8-naphthalimide was carried out by sodium nitrate in the concentrated sulfuric acid at elevated temperature. It was detected that naphthalimide (1b) had lower solubility in sulfuric acid comparing with naphthalic anhydride (1a). The yield of anhydride $\mathbf{2 a}$ was $78 \%$, the yield of imide $\mathbf{2 b}-70 \%$. 3-Nitro-1,8-naphthalimide $\mathbf{2} \mathbf{b}$ was also obtained by ammonolysis of 3-nitro-1,8-naphthalic anhydride 2 a with 93\% yield.

3-Amino-1,8-naphthalic anhydride 3a (as hydrochloride) and 3-amino-1,8-naphthalimide $\mathbf{3 b}$ were prepared by reduction of 3-nitro-1,8-naphthalic anhydride (2a) and 3-nitro-1,8-naphthalimide (2b) with sodium dithionite solution in aqueous ethanol. The reaction yielded $64 \%$ and $71 \%$ of anhydride and imide $\mathbf{3 a}$ and $\mathbf{3 b}$, respectively.

Since amino anhydride 3a is a bifunctional compound that can undergo the polymerization reaction, it needs to be converted into more stable hydrochloride. In contrast, the polymerization for 3-aminonaphthalimide is not a problem as transamination does not occur easily because of the lower reactivity of the imide carbonyl group in $\mathrm{A}_{\mathrm{N}}$ reactions. 3-Amino-1,8-naphthalimide $\mathbf{3} \mathbf{b}$ was also obtained by ammonolysis of 3-amino-1,8-naphthalic anhydride (3a) with 89\% yield.

3-Fluoro-1,8-naphthalic anhydride $\mathbf{4 a}$ and 3-fluoro-1,8-naphthalimide $\mathbf{4 b}$ were synthesized with $19 \%$ and $24 \%$ yield, respectively, by diazotization of 3-amino1,8-naphthalic anhydride and 3-amino-1,8-naphthalimide and subsequent thermal decomposition of the corresponding tetrafluoroborates. 3-Fluoronaphthalimide 4b was also obtained by ammonolysis of 3-fluoronaphthalic anhydride 4 a with the yield of $90 \%$.

3-Fluoro-1,8-naphthalic anhydride and 3-fluoro1,8-naphthalimide are light yellow crystalline substances with melting points of $221-222^{\circ} \mathrm{C}$ and $305-$ $307^{\circ} \mathrm{C}$, respectively. 
The structure of 3-fluoronaphthalic anhydride and 3 -fluoronaphthalimide was determined by IR and ${ }^{1} \mathrm{H}$ NMR spectroscopy.

The IR spectrum of anhydride 4a exhibits intense absorption bands at $1780 \mathrm{~cm}^{-1}$ and $1734 \mathrm{~cm}^{-1}$ corresponding to the stretching vibrations of carbonyl groups of the anhydride moiety. In the IR spectrum of imide $\mathbf{4 b}$ two absorption bands at $1698 \mathrm{~cm}^{-1}$ and $1674 \mathrm{~cm}^{-1}$ are observed corresponding to the characteristic stretching vibrations of the imide carbonyl groups. The presence of the $\mathrm{N}-\mathrm{H}$ bond in 3-fluoronaphthalimide is confirmed by absorption at $3170 \mathrm{~cm}^{-1}$. The absorption band at $1095-1100 \mathrm{~cm}^{-1}$ in the IR spectra of anhydride $\mathbf{4 a}$ and imide $\mathbf{4 b}$ corresponds to the stretching vibrations of the $\mathrm{C}-\mathrm{F}$ bond.

In the ${ }^{1} \mathrm{H}$ NMR spectra of compounds $\mathbf{4 a}$ and $\mathbf{4 b}$ the signals of aromatic protons resonate up-field in the range of 8.0-8.7 ppm. The signals from $\mathrm{H}^{2}$ and $\mathrm{H}^{4}$ protons are split by ${ }^{19} \mathrm{~F}$ nucleus into doublets with the coupling constant $J_{H-F}=12.4 \mathrm{~Hz}$. The signal of proton $\mathrm{H}^{6}$ is observed as a doublet of doublets due to coupling with the magnetically inequivalent $\mathrm{H}^{5}$ and $\mathrm{H}^{7}$ protons, which give rise to doublets. The signal of the imide proton in compound $\mathbf{4 b}$ appears as a singlet at $11.62 \mathrm{ppm}\left(\mathrm{d}_{6}\right.$-DMSO).

According to our results the best synthetic route to 3-fluoro-1,8-naphthalimide is as follows: 1,8-naphthalic anhydride (1a) $\rightarrow$ 3-nitro-1,8-naphthalic anhydride (2a) $\rightarrow$ 3-nitro-1,8-naphthalimide $(\mathbf{2 b}) \rightarrow$ 3-amino-1,8-naphthalimide (3b) $\rightarrow$ 3-fluoro-1,8-naphthalimide (4b).

\section{Experimental Part}

The ${ }^{1} \mathrm{H}$ NMR spectra were recorded at ambient temperature on a BRUKER WM 400 spectrometer with an operating frequency of $400 \mathrm{MHz}$, in DMSO- $\mathrm{d}_{6}$ as a solvent and TMS as the internal standard. The IR spectra (in $\mathrm{KBr}$ ) were recorded on a Perkin Elmer Frontier FT-IR spectrometer. The reaction course and purity of the compounds synthesized were monitored by thin layer chromatography on Silicagel 60 F254 plates (Merck) with chloroform as an eluent, followed by exposure to UV light. 1,8-Naphthalic anhydride and 1,8-naphthalimide were prepared from acenaphthene according to the known procedure [7].

3-Nitro-1,8-naphthalic anhydride (5-nitrobenzo[de]isochromene-1,3-dione) (2a). Add sodium nitrate (1.30 g, $15 \mathrm{mmol}$ ) portion wise to the solution of 1,8-naphthalic anhydride (3.00 g, $15 \mathrm{mmol})$ in $30 \mathrm{ml}$ of the concentrated sulfuric acid. Heat the reaction mixture for $2 \mathrm{~h}$ on a water bath, then pour onto ice, filter the precipitate, wash with water and dry at $110^{\circ} \mathrm{C}$. Purify the crude product by crystallization from acetic acid to obtain 3-nitronaphthalic anhydride as a yellow solid (2.85 g, 78\%). M.p. $-242-244^{\circ} \mathrm{C}$ [7].

3-Nitro-1,8-naphthalimide (5-nitro-1H-benzo[de] isoquinoline-1,3(2H)-dione) ( $2 \mathbf{b})$. Compound $\mathbf{2 b}$ was prepared analogously to compound 2a using naphthalimide $(2.00 \mathrm{~g})$ in $50 \mathrm{ml}$ of concentrated sulfuric acid and sodium nitrate (1.30 g). Crystallization from acetic acid yields title compound (1.70 g, 70\%) as a yellow solid. M.p. $-311-312^{\circ} \mathrm{C}$ [7].

3-Amino-1,8-naphthalic anhydride (5-aminobenzo [de]isochromene-1,3-dione) (3a). Dissolve 3-nitro-1,8naphthalic anhydride $(1.00 \mathrm{~g}, 4 \mathrm{mmol})$ in ethanol $(100 \mathrm{ml})$ and hot water $(50 \mathrm{ml})$. Add sodium dithionite $(0.55 \mathrm{~g})$ portion wise while stirring. Reflux the reaction mixture for $3 \mathrm{~h}$ and concentrate on a water bath. Add hydrochloric acid $(10 \mathrm{ml})$ to the residue, filter the precipitate and dry to obtain 3-amino-1,8naphthalic anhydride hydrochloride (0.65 g, 64\%) as an orange solid. M.p. $-290-292^{\circ} \mathrm{C}$ [7].

3-Amino-1,8-naphthalimide (5-amino-1H-benzo[de] isoquinoline-1,3(2H)-dione) ( $3 \mathbf{b})$. Compound $\mathbf{3 b}$ was prepared analogously to compound 3a using 3-nitronaphthalimide $(1 \mathrm{~g}, 4 \mathrm{mmol})$ in ethanol $(100 \mathrm{ml}) /$ hot water $(50 \mathrm{ml})$ and sodium dithionite $(0.55 \mathrm{~g})$. The title compound $(0.7 \mathrm{x} \mathrm{g}, 71 \%)$ was obtained as an orange solid. M.p. $-333-335^{\circ} \mathrm{C}$ [7].

3-Fluoro-1,8-naphthalic anhydride (5-aminobenzo[de]isochromene-1,3-dione) (4a). Heat 3-amino-1,8naphthalic anhydride $(0.5 \mathrm{~g}, 2 \mathrm{mmol})$ and hydrochloric acid ( $2 \mathrm{ml}$ ) in $10 \mathrm{ml}$ of water to reflux, then cool the mixture to $0^{\circ} \mathrm{C}$. Add the solution of sodium nitrite $(0.14 \mathrm{~g}, 0.002 \mathrm{~mol})$ in $10 \mathrm{ml}$ of water dropwise at 0 while stirring vigorously. Stir the reaction mixture for $30 \mathrm{~min}$ at $0^{\circ} \mathrm{C}$ and filter under ice cooling. Cool the filtrate to $-5^{\circ} \mathrm{C}$, add tetrafluoroboric acid $(2 \mathrm{ml})$ to the filtrate, leave the reaction mixture at $-5^{\circ} \mathrm{C}$ for $30 \mathrm{~min}$, filter the precipitate and wash with cold methanol. Dry the resulting diazonium tetrafluoroborate salt over sulfuric acid. The diazonium salt was thermally decomposed, the residue in the distillation flask was crystallized from acetic acid. 3-Fluoro-1,8-naphthalic anhydride $(0.09 \mathrm{~g}, 19 \%)$ was obtained as pale yellow solid. M.p. $-221-222^{\circ} \mathrm{C}$. IR $\left(\mathrm{KBr}, \mathrm{cm}^{-1}\right): 852$, $1016,1095,1228,1300,1338,1504,1564,1590,1734$, $1780,3030 .{ }^{1} \mathrm{H}$ NMR ( $400 \mathrm{MHz}$, DMSO-d $\left.\mathrm{d}_{6}, \delta, \mathrm{ppm}, \mathrm{J}, \mathrm{Hz}\right)$ : $8.62 \mathrm{~d}(1 \mathrm{H}), J_{H-F}=12.4\left(\mathrm{H}^{2}\right) ; 8.69 \mathrm{~d}(1 \mathrm{H}), J_{H-F}=12.4\left(\mathrm{H}^{4}\right)$; $8.09 \mathrm{~d}(1 \mathrm{H}), J_{56}=8.0\left(\mathrm{H}^{5}\right) ; 8.06 \mathrm{dd}(1 \mathrm{H}), J_{56}=8.0, J_{67}=$ $8.4\left(\mathrm{H}^{6}\right) ; 8.47 \mathrm{~d}(1 \mathrm{H}), \mathrm{J}_{67}=8.4\left(\mathrm{H}^{7}\right)$. Found, \%: C 66.72; $\mathrm{H}$ 2.31; F 8.75; $\mathrm{O} 22.17 . \mathrm{C}_{12} \mathrm{H}_{5} \mathrm{FO}_{3}$. Calculated, \%: C 66.68; H 2.33; F 8.79; 0 22.20.

3-Fluoro-1,8-naphthalimide (5-amino-1H-benzo[de] isoquinoline-1,3(2H)-dione) ( $\mathbf{4 b})$. Compound $\mathbf{3 b}$ was prepared analogously to compound $\mathbf{3 a}$ using 3-aminonaphthalimide $(0.50 \mathrm{~g}, 2 \mathrm{mmol})$ and sodium nitrite $(0.10 \mathrm{~g}, 2 \mathrm{mmol})$. The title compound $(0.10 \mathrm{~g}, 24 \%)$ was obtained as a pale yellow solid. M.p. $-305-307^{\circ} \mathrm{C}$. IR (KBr, $\left.\mathrm{cm}^{-1}\right): 850,968,1015,1100,1266,1350,1574$, $1592,1680,1728,3032,3170 .{ }^{1} \mathrm{H}$ NMR $(400 \mathrm{MHz}$, DMSO- $\left.\mathrm{d}_{6}, \delta, \mathrm{ppm}, J, \mathrm{~Hz}\right): 8.50 \mathrm{~d}(1 \mathrm{H}), J_{H-F}=8.8\left(\mathrm{H}^{2}\right)$; $8.56 \mathrm{~d}(1 \mathrm{H}), J_{H-F}=8.8\left(\mathrm{H}^{4}\right) ; 8.00 \mathrm{~d}(1 \mathrm{H}), J_{56}=8.0\left(\mathrm{H}^{5}\right)$; $7.98 \mathrm{dd}(1 \mathrm{H}), J_{56}=8.0, J_{67}=8.4\left(\mathrm{H}^{6}\right) ; 8.35 \mathrm{~d}(1 \mathrm{H}), J_{67}$ 
$\left.=8.4\left(\mathrm{H}^{7}\right) ; 11.62 \mathrm{~s}(\mathrm{~N} \underline{\mathrm{H}})\right)$. Found, \%: C 67.04; H 2.76; F 8.75; N 6.50; $\mathrm{O} 14.82 . \mathrm{C}_{12} \mathrm{H}_{6} \mathrm{FNO}_{2}$. Calculated, \%: C 66.98; H 2.81; F 8.83; N 6.51; 014.87.

Synthesis of 3-substituted 1,8-naphthalimides (2b-4b) by ammonolysis of naphthalic anhydrides $(\mathbf{2 a}-\mathbf{4 a})$. Heat the corresponding naphthalic anhydride ( $2 \mathrm{mmol}$ ) on a water bath in $20 \mathrm{ml}$ of $16 \%$ aqueous ammonia for $3 \mathrm{~h}$. Dilute the reaction mixture with $10 \mathrm{ml}$ of water. Filter the precipitate, wash with water, and dry at $110^{\circ} \mathrm{C}$. Purify the crude product by crystallization from acetic acid to obtain the corresponding naph- thalimide (1.7-1.9 mmol) with the identical melting points as of the samples above.

\section{Conclusions}

1. It has been shown that 3-nitronaphthalimide can be obtained by direct nitration of naphthalimide with a high yield.

2. 3-Fluoronaphthalimide can be synthesized with an optimal yield by the following sequence: naphthalic anhydride $\rightarrow$ 3-nitronaphthalic anhydride $\rightarrow$ 3-nitronaphthalimide $\rightarrow$ 3-fluoronaphthalimide.

\section{References}

1. Negwer M., Scharnow H.-G. Organic-chemical drugs and their synonyms. The 8th edition. Weinheim: Wiley-VCH, 2001, 4228 p.

2. Hayes B. A., Gupta S., Chang S. C. J. Labelled Compd. Radiopharm., 1996, Vol. 38, No.7, pp.607-612.

3. Eglen R. M., Bonhaus D. W., Clark R. D. Neuropharmacology, 1994, Vol. 33, No.3/4, pp.515-526.

4. Xie L., Xu Y., Wang F. Bioorg. Med. Chem., 2009, Vol. 17, No.2, pp.804-810.

5. Tan S., Yin H., Chen Z. Eur. J. Med. Chem., 2013, Vol. 62, No.4, pp.130-138.

6. Yagupolskii L. M., Ivanova Zh. M. Zh. Obshch. Khim., 1957, Vol. 27, No.8, pp.2273-2276.

7. Dashevsky M. M. Acenaphthene. M.:Khimiya, 1966, 460 p.

Надійшла до редакції 29.07.2015 p. 